\title{
Marka İletișiminde, Yeni ve Sosyal Medyada İçerik Yönetimi
}

\section{Content Management In Brand Communication, New Media and Social Media}

\author{
Saadet UĞURLU ${ }^{(*)}$
}

\section{Özet}

Hizla değişen ve yayllan bilgi iletişim teknolojileri, marka iletişiminin uygulamalarında ve iletişim sistemlerinde köklü dönüşümlere neden olmaktadır. Çalışma, yeni medya araçlarılla, bireylerin mecra olmaları ve bu alanda kullanılan, değişen 'Marka Illetişimi'ni ve değişen kitle iletişim araçlarına doğru içerik üretimini ele almaktadır. Günümüzde sosyal ve yeni medya; diyaloğa dayal, çift yönlü, etkileşimli iletişime izin veren yapısıyla, kitlelerin yönettiği yeni medya ve onların içerik yönetiminde değişimleri ortaya koymuştur. Bu çalışmada 2005-2015 yılları arasında farklı sektörlerde (inşaat, turizm, alışveriş merkezleri, perakende, sağlık, eğitim, vb.) yeni ve sosyal medyada kullanilan içerik yöntemleri gözden geçirilerek derlenerek, teorik inceleme ile nitel bir çözümleme yapılmıştır. Çalışmanın sorunsal, eski medya ile yeni medyanın içerik hazırlanırken farklı yöntemler kullanıyor olmasıdır. İdeolojik ve marka iletişimi bağlamında; sosyal ve yeni medyaya yönelik olarak kullanabileceği yöntemler, sosyal medya içerik yönetimi, içerik üretiminin saptanması bu çalışmanın temel amacını oluşturmaktadır.

Anahtar Kelimeler: Halkla İlişkiler, Sosyal Medya, Marka İletişimi, Bütünleşik Pazarlama Iletişimi, Dijital PR

(*) Yrd. Doç. Dr. Üsküdar Üniversitesi, İletişim Fakültesi, Reklam Tasarımı ve İletişimi Bölümü Öğretim Üyesi. E-mail: saadet.ugurlu@uskudar.edu.tr 


\section{Saadet UĞURLU}

Üsküdar University Journal of Social Sciences

Year:2

Issue:2

\section{Abstract}

Information communication technologies have been changed and spread rapidly so that they caused major changes in communication systems and applications of brand communication. This study discusses how new media turns individuals into medium, the changing face of brand communication and producing the right content for the mass media. In today's world, social and new media with their dialogue based two-way communication structure have showed the changes in content management and new media which is managed by the mass. In this study, a theoretical research with a qualitative analysis has been made by analyzing the content methods used in new and social media in various sectors (such as construction, tourism, shopping malls, retail, health, education etc.) from 2005 to 2015. The problematic of the study is that the old media and new media use different methods while creating content. In ideological and brand communication framework; methods which can be used in social and new media, social media content management, establishing the content production form the basic purpose of this study.

Keywords: Public Relations, Social Media, Brand Communication, Integrated Marketing Communication, Digital PR.

\section{Giriș}

Hızla gelişen teknoloji sayesinde, kullandığımız iletişim cihazları, ak1llı cep telefonları, tablet, bilgisayar, akıllı TV'ler hem mecra hem de veri bankaları olarak kullanılmaktadır. İnsanlar aplikasyonlarla, kendi gazetelerini hatta TV kanallarını oluşturarak, kendilerine sunulanları değil, kendi seçtiklerini izlemektedir. Beğendiklerini paylaşıp, böylece çevrelerine yayıncılık yapmaktadır. Ekranlar arasındaki geçişin kolaylaştığı, cihazların birbiriyle haberleştiği bu bütünleşik ortam esnekliğe, hıza ve interaktifliğe imkân sağlamaktadır. Cihazlar, bireyleri sistemin merkezine yerleştirdikleri için de insanların vazgeçilmezi haline gelmiş durumdadır. 


\section{Marka Iletișiminde, Yeni ve Sosyal Medyada Ị̇erik Yönetimi}

Yeni medya ortamları açısından iletişim disiplinine baktığımızda, yeni bir iletişim anlayışının kurumlar açısından edinilmesi gerekliliği açıktır. Bu açıdan baktığımızda yeni medyanın içinde her kullanıcı ve her marka artık aynı zamanda bir yayıncıdır. Kurumlar bu anlayışı, online stratejilerinin içerisinde daha fazla analiz etmek zorunda kalmıştır. Çünkü hedef kitleleri artık klasik kitle iletişim araçları olan gazete, televizyon ve radyonun karşısında olmakla kalmayıp, kurumun yanında gönül bağı kurması gereken kitleler haline gelmiştir. Gelişen iletişim teknolojileri, insanları, internet ve sosyal medya ile anlık iletişim kuran, sevdiği markaları yücelten, kırıldığı markaları kitlelere şikâyet etmekten çekinmeyen kitleler haline getirmiştir. $\mathrm{Bu}$ durumda kurumlar yeni ve sosyal medyada belirlenen iletişim stratejisi içerisinde, hedef kitlelerle pozitif ve etkin iletişim kurmak için çaba sarfetmeye başlamışlardır. Hatta hedef kitlelerini kendi markalarının gönüllü elçileri haline getirmeye çalışmaktadırlar.

Elektronik devrimle beraber Web 1.0, Web 2.0, Web 3.0 olarak üç temel evreye ayrılarak; 'İzle, katıl, paylaş, bütünleş' sözcükleriyle bu dönem kullanıcıları giderek pasif izleyicilerden çıkıp aktif katılımcılara dönüşmüştür. Farklılıklarını şöyle özetleyebiliriz: Web 1.0'ın iletişim dili kurumsal olup, ziyaretçileriyle etkileşim olanağı sunmayarak, web sitesinin sahibiyle bağlantı kurmak isteyenlerin formlar doldurması, üye olması veya e-posta yoluyla haberleşmesi gerekiyordu. Web 2.0 (katıl, paylaş), 2000'li yıllarla birlikte kullanıcıların gücünün kendini hissettirmeye başladığ 1 dönem olarak tanımlanabilir. Yazılım programlarındaki gelişme, bağlantı hızı ve kalitesinin artmasına paralel olarak internetin sunduğu imkânlar da çoğaldı. 1998'de doğan Google'ın kısa sürede milyarlarca dolarlık bir değere erişmesi, yatırımcıların sanal dünyaya karşı azalan ilgi ve inancının artmasını sağladi.

İnsanlar, sosyal bir varlık olduğundan birlikte olmaya ihtiyaç duyup; paylaşımları, beğenileri, özentileri, kıskançlıkları, merakları, zevkleriyle tüm iletişim süreçlerini ve kurallarını yeniden şekillendirmiştir. Dijital çağda, "müşteri odaklı" yerine "insan odaklı" bir bakış açısına sahip 


\section{Saadet UĞURLU}

olmadan, etkin, verimli ve sürdürülebilir bir etkileşim kurmak imkânsız hale geldi. Bütünleşik pazarlama iletişim stratejisini toplumun ihtiyaçları üzerine kurmak ve fayda/değer sağlamak üzere temellendirmemiz zorunlu bir hal almıştır. Günümüz kurum ve firmaları, tüketici tanımı yerine "insan odaklı" strateji oluşturulmalı. Hedef kitle yerine de "hedefleri olan kitleler" olarak tanımlamalı. Günümüzde hedefleri olan kitlelere ulaşmada, onlarla doğru iletişim kurmanın yollarından olan dijital araçların ön plana çıkmasının temelinde ise insanların birlikte olma ihtiyacı yatmaktadır.

Marka iletişiminin stratejisi ve süreci yukarıda bahsettiğimiz değişimden etkilenmiş, geleneksel anlayış yerine interaktif anlayışa yönelmiştir. İnteraktif halkla ilişkiler anlayışının doğması da internetin hayatımıza girmesi ile başlamıştır. Geleneksel kitle iletişim araçlarına internet ile beraber yeni araçlar katılmıştır (e-mail, web site, video, blog, mobil, vb.).

Üsküdar University Journal of Social Sciences Year:2 Issue:2 Her geçen gün değişen bu gelişime firma ve markaların ayak uydurması, zorunlu bir hal almıştır. Geleneksel pazarlama iletişim anlayışına internetin katkısı ile daha etkileşimli, stratejik iletişim yönetimi anlayışı yerleşmiştir. Kitle iletişim araçlarının bütünleşik pazarlama iletişiminde gerek içerik oluşumunda, gerek farklı disiplinlerin iç içe geçmesi nedeniyle çoklu kullanımı, ölçümlenebilen, etkileşimi aktif olan araçların geleneksel kitle iletişim araçlarından farklı olarak; kendi medyasını, kendi gündemini oluşturan kurum, kuruluş, marka ve kişilerin medyası haline gelmiştir. Onların medyası ile marka yönetimi ve pazarlama iletişimi sağlanmaktadır. Sayısı belli olmayan mecralar dünyasında hedef kitleye ulaşabilmek ve olumlu izlenimler bırakabilmek hiç de kolay olmayabilir. İnternet kanalıyla gerçekleştirilen iletişimin en önemli avantajlarından bir tanesi, kitle iletişim araçlarında eşik bekçilerinin yerine getirdikleri filtre işlevinin, web siteleri aracılığıyla gerçekleştirilen iletişim açısından geçerli olmaması ve kontrolünün kurumun elinde bulunmasıdır. ${ }^{1}$ Günümüzde kitleleri yöneten medya yerine hem kitlesel hem bireysel iletişim imkânı sunan, kitlenin yönettiği medyadan bahsedebiliriz. 


\section{Marka Iletișiminde, Yeni ve Sosyal Medyada İcerik Yönetimi}

\section{Kitle İletișim Araçlarına Tarihsel ve Kuramsal Bakıș}

Toplumlar asırlar boyunca bir dizi devrimler yaşamıştır. 1950'lerin ortasındaiyice görülmeye başlanan devrimlerin ilki elektronik devrimi, ikincisi ise bilgisayara dayalı bilgi devrimidir. Elektronik devrimi, Batı kültürünü makine çağından "İletişim Çağı"na götürürken; bu, değişik ekonomik ve siyasal ilişkilerdeki değişikliklerle toplumsal tutumlar, inanç sistemleri ve kuruluşlardaki köklü değişiklikleri beraberinde getirmiştir. İletişim tarihi sadece günümüz medya teknolojilerinin tarihinden ibaret değildir. İnsan, temel bir iletişim gücü olarak varlığını sürdürebilmek ve geliştirebilmek için kendisiyle, doğayla ve diğer insanlarla iletişim kurmuş; bu ise insanın kendisinin, doğanın ve toplumun dönüşümüne katkı yapmıştır. İnsanın bilinci sadece birey ile onu çevreleyen doğa arasındaki ilişki değil, toplum ile çevresi arasındaki ilişkinin bireyde yansıyan toplumsal bir imgesidir. İnsanın içinde yer aldığı toplumsal ilişkilerin tümü insanın duyumlarını düzenleyen kavramsal ve kuramsal çerçeveyi (yani dilini) biçimlendirir. ${ }^{2}$

Harold Adam Innis ve Marshal McLuhan gibi düşünürler, insanların kullandığ 1 iletişim teknolojilerini toplumsal ve ekonomik yapının temel belirleyicisi olarak kabul eder. Farklı dönemlerde egemen olan farklı iletişim teknolojileri, toplumların nasıl örgütleneceğini belirler. Teknoloji her zaman içeriği belirler. McLuhan'a (1967) göre, kitle iletişim araçlarının gelişimi ile dünya, küresel büyüklükte bir köye dönüşmüştür. ${ }^{3}$ Böylece dünya küçülmüş ve birbirine bağlanmıştır. Uydu haberleşmesinin gelişmesi zaman ve mekân farklarını ortadan kaldırmıştır. Psikolog Elihu Katz'ın “Kullanımlar ve Doyumlar” yaklaşımına göre insanların toplumsal ve psikolojik kökenli ihtiyaçları vardır. İnsanlar belirli medya içeriklerini tüketerek ihtiyaçlarını giderirler. Bu yaklaşım ilk dönem etki araştırmalarının aksine izleyici ve tüketicileri pasif konumdan çıkararak onlara belli bir düzeyde aktiflik atfeder. ${ }^{4}$

2 G. Thomson, İnsanın Özü, çev: Celal Üstel, (İstanbul: Payel Basım 1976), s.22.

3 Akt. Levent Yaylagül, Kitle İletişim Kuramları, (Ankara: Dipnot Basım 2013), s.70

4 A.g.e s.72. 


\section{Saadet UĞURLU}

Tarihsel süreç içerisinde geliştirilen çeşitli teknolojik araçlarla yüz yüze iletişimin yanı sıra teknolojiyle aracılanmış iletişim tarzları da geliştirmişlerdir. Bunlar, yazılan bir mektuptan, çekilen bir telgraf ya da faksa, dinlenilen bir radyo programından, izlenilen bir televizyon programına ya da sinema filminden gönderilen bir e-posta mesajına kadar değişir. Teknoloji kendi başına bağımsız bir değişken olarak alınamaz. Ancak zaman ve mekânın örgütlenmesini sağlayan üretim tarzı ile ilişkilendirildiğinde anlam kazanır. ${ }^{5}$ Kitle iletişimin gelişmesi bilimsel alandaki başka gelişmelerin oluşturduğu bir temel üzerine kurulmuştur. Mcluhan'a göre, insan eliyle oluşturulmuş bütün yapılar; dil, yasalar, fikirler ve varsayımlar, aletler, giysiler ve bilgisayarlar, insan bedeninin uzantısı olarak görünür. ${ }^{6}$

Böylelikle tarihsel süreçte tüm kitle iletişim araçlarının, toplumun

Üsküdar University Journal of Social Sciences

Year:2

Issue:2 ve bireyin kendi ihtiyaçları doğrultusunda ve yenilikleri içerisine dahil ederek geliştirilen kültürel keşifler olduğu söylenebilir. Radyo ve telefon kulağın uzantıları, film ise başlangıçta hem kasların hem sinir sisteminin uzantısı olmuştur. En sonunda beynin bir uzantısı olarak bilgisayar ortaya çıkmıştır. Stonier, bilgisayarı insanın nörolojik yeteneklerinin uzantılarını sağlamak olarak tanımlamıştır. ${ }^{7}$ Teknolojinin işlevi her zaman, insanların yeteneklerini geliştirmek olmuştur. Sanayi Devrimi, insanların kaslarının uzantısı olan aygıtlarla ilgilenmiştir. Elektronik Devrimi, insanların sinir sistemlerinin uzantısı olan aygitlarla ilgilenmektedir.

1440 yılında Gutenberg'in geliştirdiği ilk matbaayla birlikte, bilginin kâğıt üzerinde çoğaltılması ve dağıtılması artık mümkün olmuştu. Bilgi çoğaldıkça öğrenen ve bilinçlenen toplulukların sesi daha güçlü çıkar oldu, aynı fikirde olan farklı kitleler bir araya gelmeye başladı. Birbirlerine güç oldular. Sosyolojik değişimlerin nedeni de sayılabilecek matbaa, diğer

5 A.g.e., s. 17.

6 Marshall Mcluhan ve Bruce R.Povers, Global Köy, çev. Bahar Ö.Düzgören, (İstanbul: Scala Yayın 2001), s.123.

7 Tom T. Stonier, The Communicative Society, çev. Nur Nirven, IPRA-HDD Altın Kitap 5: Iletișim Toplumu, (İstanbul: Rota Yayınlar1 1998), s.15. 


\section{Marka Iletișiminde, Yeni ve Sosyal Medyada İcerik Yönetimi}

yeniliklerle beraber 14. ve 17. yüzyıl arasında önce Avrupa'nın yapısını değiştiren reform sürecini ve diğer ülkelerin de değişimini hızlandıran temel unsurlardan sayılabilirler. Çünkü bilginin belli bir sınıf gözetmeden toplumun her kesimine kadar ulaşması feodal dönemin sonunu hazırladı. İnsanlar öğrendikçe daha fazla bilgi üretti; kültür oluşturdu, daha özgür yaşamak ve eşit haklar istedi. Günümüzdeki e-devrim süreci de önce elektronik, internet, dijitalleşme ile bilgi üretimi ve paylaşımı parmağınızın ucunda ve çok hızlı. Dünyanın bir ucunda gerçekleşen herhangi bir konudan, evimizde gerek bilgisayar gerekse de mobil cihazlarımızdan anında haberdar olabiliyoruz. Bilgiye erişimdeki özgürlük, toplumu daha da güçlü kılmaktadır. İnternetin daha geniş kitlelere, daha hızlı ve daha etkili biçimde erişebilme olanağı sağlaması iletişim uygulamaları için de bu aracı kaçınılmaz kılmıştır. Oysa yeni iletişim teknolojilerinin bu uygulamaları nasıl ve ne amaçla değiştirdiği sorusu henüz yanıtlanmış değildir. Bilgiye erişmenin değil, onu kullanabilmenin önem kazandığı bir dönemin başladığı vurgulanmaktadır. ${ }^{8}$

Manuel Castells yeni medyanın gelişiminin sonuçları arasına medya iletilerinin çeşitlenmesi ve sermayenin yeniden yapılanmasını koymuştur. "Enformasyonalizm" daha bilgi-temelli ve daha az hiyerarşik yapılar aracılığıyla kuruluşların artan bir esneklik kazanmasını sağlamıştır. Gelecek, insan çeşitliliğini bastıran, kitle yönelimli, homojen bir kültürden çok, rekabet üstünlüğünün ürün farklılaştırma ve izleyici bölümleme yoluyla kazanıldığı, çeşitlilik gösteren bir popüler kültürün yönetiminde olacaktır. Castells'e göre, "Biz küresel bir köyde değil; küresel olarak üretilip yerel olarak dağıtılan, kişiye özel kulübelerde yaşamaktayız" tanımındaki gibi küresel olarak üretilip yerel olarak dağıtılan, kişiye özel mesajlarla "toplumsallık" daha da gelişmektedir. ${ }^{10}$ Böylelikle kitle iletişim

8 Filiz Balta Peltekoğlu, a.g.e., s.307.

9 Manuel Castells, Information Technology, Globalisation and Social Development, UNRISD Conference On Information Technologies and Social Development, Plais des Nations, Cenova, 22-24 Haziran 1998, Akt. Levent Yaylagül, a.g.e., s.311.

10 Manuel Castells, The Rise of the Network Society; The Information Age: Economy, Society and Culture, Volume 1, (Blackwell, Oxford 1996), Akt. Levent Yaylagül, a.g.e., s.315. 


\section{Saadet UĞURLU}

araçlarıyla küreselleşen tek bir köy haline gelen bu dünya düzeninde, iletişim araçlarının etkileşimiyle bilgi ve ileti aktarmanın yanı sıra, tüketicinin kendi istek ve davranışlarını da interaktiflik ve veri kullanımlarıyla çözümleme ve ona göre üretime geçmesiyle birlikte yeni iletişim teknolojileri araçlarıyla beraber tüketici artık üretici de olmuştur.

Ünlü Amerikalı gazeteci Thomas Friedman 2004'te yayınlanan "The World is Flat-Dünya Düzdür” kitabında, internetin dünyayı düzleştirmekte olduğuna dikkat çekmiştir. Burada kastedilen şey, internetle beraber coğrafi sınırların kalkarak, kıtaların birleşmesi, mesafelerin azalması, milyarlarca insanın birbiriyle artık iletişime girebiliyor olması sonucunda "küresel köy" tanımının gerçekleşmesidir. ${ }^{11}$ Diğer taraftan kitleleri yöneten mecra bir yandan da kitlenin yönettiği bir mecra haline geldi. Küçük bir cep telefonuyla, dünyanın uzak bir ülkesinde bir haber yakalayan bir kişi, bunu

Üsküdar University Journal of Social Sciences Year:2 Issue:2 internette yayınladığında tüm basın kuruluşlarını atlatan bir muhabire dönüşebiliyor. Saniye bazında içerik üretiminin zorunlu hale geldiği ortamda haberler, saniye bazında güncellenmektedir.

\section{Marka Illetișiminde Yeni Akım: Dijital Pazarlama İletișimi}

Geleneksel mecraların yanına eklenen dijital enstrümanlar pazarlama iletişimini de büyük ölçüde değiştirmiştir. Geleneksel mecralarda çalışmaya alışan firmalar ve ajanslar açısından yeni bir dönem başlamıştır. Artık devasa bütçeler gerektiren televizyon ve yazılı basın reklamlarının yerini daha mütevazı rakamlarla çok daha etkili sonuçlar yaratabilecek dijital ve sosyal işler almıştır.

İnternetten önce pazarlama, markalama ve reklamdan ibaretti ve fark edilmeye bağlıydı. Tek yönlüydü ve sadece ürün satmaya yönelikti. İletişim, medya ve planlamacılar ile yapılıyordu ve pazara doğrudan ulaşmak mümkün değildi. İnternet kuralları değiştirdi. Şimdi artık hedef kitlenin duymak istediği mesajları pazarın en küçük dilimine bile ulaştırmak

11 Thomas L.Friedman, Dünya Düzdür, (İstanbul: Boyner Yayınları 2006). 


\section{Marka Iletișiminde, Yeni ve Sosyal Medyada İcerik Yönetimi}

mümkün. Reklam için büyük para harcamadan tüketiciye ulaşmak için başka firsatlar doğuyor. İnsanların dikkatini doğru içerik ve doğru reklamla çekmeyi başarmak gerekiyor. Hatta tüm araçları çoklu kullanım ile en etkin ve efektif kullanabilmek imkânı da mevcut.

Yeni, hızlı gelişen, çabuk eskiyen ve çokça tüketilen bir medya ortamıyla karşı karşıyayız. Her ne kadar çok büyük bütçeler gerektirmiyor olsa da hiçbir firmanın ya da markanın ne zaman ne de para kaybetmeye tahammülü olmadığından; dijital pazarlama iletişiminin birbirinden farklı bir içerik ve farklı bir işleyişe sahip platformlarını; etkili, verimli, karlı bir şekilde kullanması gerekiyor.

Türkiye'nin tek kanallı televizyonunun ulaştığı geniş kitlelere tek bir mecradan ulaşmamız artık çok zor. Her geçen gün kitlelere ulaşan mecraların sayıları artmaktadır. Yeni mecra hızla geleneksel olabiliyor. Ya da geleneksel ve yeni mecralar birleşme gösterebiliyorlar. Tek başına ya da çoklu kullanımlara en uygun olan günümüzün dinamik, interaktif mecrası ise dijital ve yeni medyadır. Dijital pazarlama, geleneksel (gazete, televizyon, radyo, dergi, vb.) mecraların dişında internetle beraber gelen dijital teknolojinin ürettiği mecraların kullanımlarıdır. İnternetin doğuşuyla başlayan yeni medya yeni mecralar aynı hızla pazarlamada kullanılmaya başlanmıştır. Pazarlama iletişiminde doğru kitlelerin saptanması onların tutum, kanaat ve davranışlarını belirlemeyi onlara ulaşabileceğimiz doğru mecraların bulunmasını ehemmiyetli kılmıştır. Dijital pazarlama uygulamalarına banner, video, e-posta, SMS, MMS, Mobil, Blog, web, yer imleri vb pek çok örneği verebiliriz.

Dijital pazarlamayı W.L. Neuman'a göre, coğrafi uzaklıkları bir engel olmaktan çıkaran, iletişimin gücünden çok büyük artışlar ortaya çıkaracak, iletişim hızının artması için olanaklar yaratacak, interaktif iletişim için çeşitli imkânlar sağlayacak, birtakım bağımsız iletişim yöntemlerinin birbirleriyle ilintilendirilmesinin önünü açacak gelişmeler olarak tanımlayabiliriz. ${ }^{12}$

12 Akt., İzzet Bozkurt, Pazarlama İletişiminde Sihirli Dokunuşlar, (İstanbul:Mediacat 2013), s.178. 


\section{Saadet UĞURLU}

Üsküdar University Journal of Social Sciences Year:2 Issue:2

Bütünleşik pazarlama iletişimi Bozkurt'a göre, artık pazarlama, televizyon ve radyo gibi geleneksel araçlarla geniş, heterojen ve kimliği belirsiz hedef kitlelere hitap etme biçimini, geribildirim almanın çok daha kolay ve kesin olduğu yöntemlere dönüştürmüştür. $\mathrm{Bu}$ durum bireysel tepkinin öneminin artmasına bağlanabilir. Başka bir deyişle, tek yönlü pazarlama, yerini interaktif ve ölçülebilir süreçlere bırakmaya başlamıştır. ${ }^{13}$ Dijital pazarlama iletişimi, halkla ilişkilerle birçok farklı alanda kesiştirdi. Son yıllarda çıkan dijital mecraların iletişim yönetiminde ve uygun içerik üretilmesinde ortaya yeni kavramlar da çıkmıştır. Medya yakınsaması ve veri tabanlı pazarlama ya da müşteri deneyimi yönetimi de bütünleşik pazarlama iletişiminde temel disiplinler haline gelmektedir.

Firma ya da markaların farklılaştırılmasında kullanılan tüm argümanlar gibi dijital mecraların sebep ve sonuç ilişkileri mutlaka önceden planlanmalıdır. Dijital mecralar stratejinin en rahat kullanıldığı alanlardır. Etkileşim ve diyaloğa açık bir iletişime olanak sağlaması beklenen yeni medyanın da bu geleneksel anlayış içinde uygulanmaya çalışıldığ gözlemlenmektedir. Halkla ilişkiler, dijital zeminde etkinliği günden güne artan; ağızdan ağıza, sosyal pazarlama ve mobil pazarlama ile aynı uyumda, her mecraya uygun içerik oluşturarak daha etkin kullanılmaya başlanmıştır. Hatta iletişim stratejileri artık yıllık planlanan bütünleşik pazarlama iletişiminin bir parçası haline gelmiştir.

Dünyanın hızlı değişimi, finansal kriz, yoksulluk, işsizliğin artması, çevresel değişim iklim değişikliği, vb. nüfus artışı ülkeleri ve firmaları bakış açılarını değiştirmek zorunda bırakmıştır. Teknolojik ve mekanik bir dünyadan internet, bilgisayar, cep telefonları ve sosyal medyalı dijital bir dünyaya değişim; üretici ve tüketicilerin davranış biçimlerini ciddi biçimde etkilemiştir. Modern pazarlamanın duayen ismi Philip Kotler, Pazarlama 3.0 kitabında; katılım ve işbirliğine dayalı bu yeni çağda, iş dünyasına şekil veren kuvvetlerle beraber yeni kurallar açıklamıştır.

13 A.g.e., s.182. 


\section{Marka Iletișiminde, Yeni ve Sosyal Medyada İcerik Yönetimi}

Kotler'a göre ${ }^{14}$, sonaltmışyıl içindepazarlama, ürün-merkezli (Pazarlama 1.0) olmaktan tüketici-merkezli (Pazarlama 2.0) olmaya yönelip son olarak da şirketlerin odak noktalarını ürünlerden tüketicilere ve insanlığın karşı karşıya kaldığı sorunlara doğru şekillendirmeye başlamıştır. Pazarlama 3.0, şirketlerin tüketici-merkezli olmaktan insan-merkezli olmaya doğru kaydıklarını ve karlılığın kurumsal sorumlulukla dengelendiği bir aşamaya gelindiğini vurgulamaktadır. Pazarlama 3.0 kitabında Kotler, değere dayalı pazarlama çağının doğuşuna tanıklık ettiğimizi, insanları sadece tüketici olarak görmek yerine, onlara akl1, kalbi ve ruhu olan 'insanlar' olarak yaklaşılması gerektiğini belirtmektedir. Aslında insanların ve tüketicilerin kendi geleceklerini, kendi kaygılarını firmalarla işbirliği yaparak beraber çözüm bulmaya yöneldiklerini bunu da sosyal medya ve ağlarla yaptığını günümüzde birçok örnekte görmekteyiz. Tüketiciler artık seçtikleri ürün ya da hizmetlerin sadece işlevsel ya da duygusal tatminlerini aramıyorlar, genel anlamda insan ve toplumun ruhunu tatmin etmesini ve daha yaşanabilir bir dünya istiyorlar.

Sosyal medyanın yükselmesiyle kendini daha da gösteren katılım çağında; haberleri, fikirleri ve eğlenceyi insanlar yaratır ve insanlar tüketir oldular. Yeni dalga teknoloji insanların, tüketiciden üretici-tüketiciye dönüşmesini mümkün kılmaktadır. Kotler bu gelişmeyi iki başlık altında toplamıştır:

1. Anlatımcı Sosyal Medya: Sosyal medyanın giderek daha da anlatımc1 bir özellik kazanmasıyla, tüketicilerin görüş ve deneyimlerini aktararak diğer tüketicileri etkileme gücü de artmaktadır. Düşük maliyetli ve tarafsız olduğu için sosyal medya, pazarlama, iletişimin geleceği olarak görülmektedir. Böylelikle alacağımız ürün ya da hizmetleri satın almadan önce edinilen müşteri deneyimi, görüşleri sitelerden okunarak satın alma kararını etkileyebiliyor. Ya da bunun tam tersi şirketler, ürün ya da hizmetlerini piyasaya çıkarmadan hedef kitlelerini sosyal ağlar vasıtasıyla

14 Philip Kotler, Hermann Kartaya, Iwan Setiawan, Pazarlama 3.0, çev: Kıvanç Dündar, (İstanbul: Optimist 2010), s.9 


\section{Saadet UĞURLU}

gözlemleyerek ürün-tüketici reaksiyonunu test etme imkânı bulabiliyor. Halkla ilişkilerin çift yönlü iletişimi, dijital ve sosyal ağlarda etkileşiminin sağlanabilmesi açısından dikkat çeken bir mecra haline gelmiştir ve bu durumun uzun vadeli olacağına inanılmaktadır. Bloglar, Twitter, Youtube, Facebook, vb

2. İşbirlikçi Katılım: Katılımlarda anlatımların yanı sıra işbirlikçi olarak kullanılmasıyla da sosyal medya farklı bir mecra olma özelliğini devam ettirmektedir. İlklerden olan Wikipedia ile başlayan işbirliği katılımlarında ayrıca gönüllülük esasına dayandırılarak kişilere mecrayı yöneten kişi olma hakkı verilmektedir. Türkiye'de de Ekşi sözlük ve benzeri çeşitli forumlarda kişiler yeri geldiğinde editör, yeri geldiğinde ürün ya da hizmeti tanıtan köşe yazarları olarak referans noktası olabilmektedirler.

Üsküdar University Journal of Social Sciences Year:2 Issue:2

Günümüzde firma ve markalar "Bağlan ve Geliştir" stratejisi kullanarak pek çok yeni ürün geliştirmişlerdir. Tüketim görüşlerini alarak ayn1 zamanda "Duygusal Pazarlama" da yapmaktadırlar. Tüketiciler artık tek değil birbirleriyle bağlantılı, bilinçli, bilgi sahibi, araştırmacı, sorgulayıcı, aktif ve geribildirimi yüksek bireylerdir.

Pazarlama literatüründe "İlk Karar Anı Teorisi”ne (First Moment Of Truth-FMOT) göre, reklam mesajıyla karşılaştığımızda bir ihtiyacımız tetikleniyor, ikinci aşamada markete gidiyoruz, raftaki ürünle karşılaşıyoruz ve hali hazırda ikna olduğumuz için satın alıyoruz. Sonra eve gidip kullanıyoruz ve reklamdaki vaat doğru mu bakıyoruz. Hayatımıza yeni medya entegre olmadan önce karar anı, ilk aşamada ilgi çeken, ikinci aşamada dağıtım noktası yani rafa yönlendiren ve üçüncü aşamada deneyimi idi. Shopper Sciences şirketi ve arama devi Google tarafından gerçekleştirilen çalışmaya göre artık bu karar anı teorisi değişti: FMOT, Zero Moment of Truth-ZMOT’a (Anlık Karar Anı) dönüştü. Tüketiciler herhangi bir ürünü duyduklarında ilk tepkileri "Bir internete bakayım/araştırayım" oluyor. ${ }^{15}$

$15 \mathrm{https} / /$ ssl.gstatic.com/think/docs/2012-zmot-handbook_research-studies.pdf ZMOT - Ways to Win Shoppers at the Zero Moment of Truth, Google Inc., Haziran 2012, s.7 


\section{Marka Iletișiminde, Yeni ve Sosyal Medyada Ị̇erik Yönetimi}

Cep telefonları ya da PC'lerinden bilgiye eriştikleri o karar verme anını yakalamak çok önemli. Buna "Zero Moment of Truth" deniyor. Artık reklamı gördügümüz andan itibaren ihtiyacımız tetiklendiyse internette araştırıyoruz, ürünü kullanan diğer kişilerin yorumlarını okuyabiliyoruz. İkna olup, satın alıp, kullandıktan sonra ürünle ilgili fikrimiz olumsuzsa bunu yine internette paylaşıyoruz ve başka birinin "raf" aşamasını yok edebiliyoruz. Bugün hedef kitleyle iletişimde olmak, tek bir kanaldan mesajlarla sınırlı değil. Onlar sizinle iletişim kurmak istediklerinde onlara cevap verebiliyor olmanız gerekli. Sadece firmanın istediği zaman değil, hedef kitlenizin istediği zaman.

Müşterilerin kendi aralarındaki konuşmalara reklamlardan daha fazla güvendiğini gören kuruluşlar, sosyal mecrada kendilerine yer açmaya çalışılar ve internet reklamlarına ağırlık verdiler. Böylece, internetin geleneksel mecralardan aldığı pay da düzenli olarak arttı. Mecra bazında global reklam harcamalarına bakarsak; Zenith Optimedia verilerine bakıldığında, 2005 yılında televizyon, gazete, dergi, radyo ve açık havadan sonra dünyanın en büyük altıncı reklam mecrası olan internet, bugün itibarıyla bu sıralamada ikinciliği aldı. İnternet, 2013 global reklam harcamalarından yüzde 20,6'lık pay almayı başardı. Bu oranın 2016'da yüzde 26,6'ya ulaşması yine tahminler arasında. Dünya çapındaki reklam harcamalarının 2014 'te yüzde 5,3;2015'te yüzde 5,8 artması ve nihayetinde 2016 yılında 2013'e nazaran yüzde 3,6 yükselmiş olması bekleniyor.

\section{Yeni ve Sosyal Medyada İçerik Yönetimi}

Teknolojinin gelişimiyle birlikte ileri teknolojik özelliklere sahip tüketici elektroniği ürünleri sahipliğinde yıllar içinde yükseliş gözlemlenmektedir. Cep telefonunun gücünün artmasıyla beraber hayatımızdaki önemli rolü de giderek artıyor. Hızla gelişen teknoloji sayesinde, cihazların kendileri birer mecra haline geldi. Hatta var olan mecralar akıllı cep telefonları, tablet, bilgisayar, akıllı TV, veri bankaları haline geldiler. İnsanlar, aplikasyonlarla, kendi gazetelerini hatta TV kanallarını oluşturarak, kendilerine sunulanları 


\section{Saadet UĞURLU}

değil, seçtiklerini izliyorlar, beğendiklerinipaylaşıyorlar, böylece çevrelerine yayıncılık yapıyorlar. Ekranlar arasındaki geçişin kolaylaştı̆̆ cihazların birbiriyle haberleştiği bu bütünleşik ortam, esneklik, hız ve interaktiflik imkân sağlıyor. Cihazlar, bireyleri sistemin merkezlerine yerleştirdikleri için de insanların vazgeçilmezi haline geldiler bile. Yeni nesil internet ve bilgisayarın, elektrik ve su gibi doğal ihtiyaç olarak görüldüğünü uzmanlar aktarmaktadırlar.

Yöntem: Bu çalışmada 2005-2015 yılları arasında farklı sektörlerde (inşaat, turizm, alışveriş merkezleri, perakende, sağlık, eğitim, vb.) yeni ve sosyal medyada kullanılan içerik yöntemleri gözden geçirilerek derlenerek, teorik inceleme ile nitel bir çözümleme yapılmıştır. Çalışmanın sorunsalı, eski medya ile yeni medyanın içerik hazırlanırken farklı yöntemler kullanıyor olmasıdır.

Üsküdar University Journal of Social Sciences Year:2 Issue:2

Yeni Nesil Medya Planlaması: Kazanılan medya/satın alınan medya/sahip olunan medya günümüzde, iletişim planlarının çok katmanlı ve esnek olarak hazırlanmasını ve kullanıcıların tepkilerine göre sürekli güncellenmesini gerektiriyor. Etkili sonuçlar elde etmek için medya planlarını satın alınan, sahip olunan ve kazanılan medya olmak üzere ayıran Karahasan'a göre, geleneksel pazarlamada satın alınan medya, dikkati satın almak üzerine kuruludur ${ }^{16}$; gazete, televizyon, radyo ve açık hava mecralarının dilimlerinin satış ve pazarlaması temellidir. Sahip olunan medya, bir şirketin satış noktaları, taşıtları, kurumsal yayınları, blog, web sitesi gibi müşterilerle doğrudan iletişim kurabileceği çok değerli mecralardır. $\mathrm{Bu}$ alanların kontrolü tümüyle firmaların kendisindedir. Kazanılan medyada ise kullanıcılarımızın paylaşmaya değer buldukları malzemeleri büyük bir süratle yayabileceğini hesaba katarak üretebileceğimiz içeriğin, insanların yaşamlarına girebilecek malzemelerle donatılmasıdır. ${ }^{17}$ Şirketlere ait sahip olunan ya da satın alınan her tür medyanın kazanılan medyaya dönüştürülmesidir.

16 Fatoş Karahasan, Taşlar Yerinden Oynarken, (İstanbul: Doğan 2012), s. 239. 17 A.g.e., s: 245. 


\section{Marka Iletișiminde, Yeni ve Sosyal Medyada İcerik Yönetimi}

Yeni medyalar, asıl medyanın içerik üreten alanı olduğu gerçekliğini yansıtmaktadır. Araçların doğru kullanım alanı, özelliklerinin kavranmasının yanı sıra uzun soluklu ve etkin şekilde kullanımı için veri toplama ile ölçümleme, en önemli konulardandır.

1. Sosyal Medya Kullanımı. Sosyal CRM/Sosyal Reklamlar: Günümüzde yeni medyanın altında yeni bir oluşum bulunmaktadır. Bu yeni oluşum "Sosyal Medya" olarak adlandirıldı. Sosyal medya teknolojilerin ve uygulamaların insanların fikirlerini, algılarını, deneyimlerini, öngörülerini çevrimiçi olarak paylaşılmasıdır (videolar, bloglar, müzikler, fotoğraflar ve haberler vb.).

2. Mobil Kullanımı: Cep telefonu ve tabletler, iPad, android içerisinde birçok farklı özellikleriyle tüketicilere özgürlüğü, eğlenceyi beraber sunabilme imkânı yüzünden, her gün satın alma oranları ve günlük kullanım süreleri hızla artmaktadır. Marka ve firmalar da tüm dijital reklam unsurlarını, tablete özel versiyonlar hazırlayarak, mobil kullanıma ehemmiyet verdiklerini göstermektedirler. Daha çok çoklu kullanım olarak da karşımıza çıkmaktadırlar. Tabletler, uygulamalar arttıkça reklam veren firmalar tüketicilerin dokunma, sallama, ses gibi yeni ve eğlenceli interaktif özelliklerle dikkatini daha fazla çekerek, uygun markaların hedef kitleleri için yepyeni deneyimleri beraberinde getirecek gibi gözükmektedir.

3. Lokasyon Bazlı Pazarlama: Tüketicilerin bulunduğu yere göre içerik gösterimi diyebiliriz. Günümüzde birçok AVM ve perakende noktasında gezerken cep telefonunuza gelen mesaj ile size kurum içerisinde bir ikram, indirim, firsat mesajı gönderilebiliyor.

4. Entegre Kampanyalar/Dijital Reklamlar: Kullanıcıların davranışları da sahip oldukları cihazlara göre değişiyor. Önceden televizyon izlerken sadece programa odaklanırken artık bir yandan sosyal ağ hesabımıza göz atıor, maillerimizi kontrol ediyor ve hatta tabletlerimizden aynı anda başka bir programı daha izlemeyi tercih ediyoruz. Mobil cihazlar taşınabilir olduklarından kullanıcıları da çoklu davranışlar (multi-tasking) 


\section{Saadet UĞURLU}

göstermeye itiyor. Reklam verenler de dijitalde reklamlarını çoklu biçimde kullanmaktadır.

5. İternetten Çevrimiçi Video ve Internet TV: Günümüzde hemen hemen herkesin elinde bir video kaydedici bulunmaktadır. Online video ile içerik yaratmak ve paylaşmak artık çok kolay. Yeni uygulamalarla video paylaşımı daha da artacaktır. Youtube ve benzeri platformlar reklam verenlerin de ilgisini şimdiden çekti ve reklam kullanımını da artık mümkün kıldı.

6. E-Ticaret: İnternet ve pazarlamanın satış amaçlı buluştuğu, pazarlamanın başarısının ölçüldüğü gelir sağlama çabaları ve satış çalışmalarının birebir yapıldığı noktadır. Yüz yüze ve telefon ile satıştan hemen sonra yapılan bilişim ve bankacılık sektörünün özel düzenlemeleriyle gelişen bu alan şu anda her noktada görülmektedir. Bazen uygulama

Üsküdar University Journal of Social Sciences Year:2 Issue:2 indirirken bazen de beğendiğiniz ürünü mağazası yerine yine markanın kendi e-mağazasından kredi kartı ile yapılabileceği gibi, sadece alışveriş konseptli internet sitelerinden de kolaylıkla yapabiliyoruz.

7. Oyunlaştırma: Artık biz onları değil oyunlar bizi yönetiyor. Kariyerimiz, kişiliğimiz ne olursa olsun herkese uygun her daim elimizde bir oyun var. Oyun mekanizmasıyla pazarlamada müşteri ilişkileri yönetiminde puan, ödül, veri paylaşımlarıyla istediğiniz hedef kitle ile birebir etkileşimdesiniz. Firmalar kendilerine özel oyunlar da tasarlamaktadırlar. Ya da firma logolarını seçtikleri oyun içerisine dahil edebiliyorlar.

8. Google Adwords/Display/Plus+: Temmuz 2011'de hayatımıza giren Google Plus, ilk bir ay içerisinde 25 milyon kullanıcıya ulaşmış sosyal ağımız oldu. En önemli özelliği, arama motoru reklamcıllğı ile sosyal medya pazarlamasını birleştirmesidir. Bu sayfaların markalara sağladığı avantajların başında ilgili anahtar kelimelerle doğal arama sonuçlarında yukarıda çıkma özelliği mevcuttur. Ayrıca Adwords reklamlarını da aynı panelden yönetme pratikliği ve analistleri de hizmet kapsamındadır. Bunun yanında markanın Hangout fonksiyonuyla kendi çevresiyle görüntülü chat yapabilme özellikleri de cazip noktalardandır. Google Reader'ın da Plus 


\section{Marka Iletișiminde, Yeni ve Sosyal Medyada İcerik Yönetimi}

içine entegre edilmesiyle arama, bilgi ve haber medyası daha sosyal bir hale gelmektedir.

9. Veri Yönetimi: Geniş ve karmaşık veri yönetimi önümüzdeki dönemin yükselen trendi gibi görülmektedir. Etkin pazarlama programlarını hayata geçirmek için tüketici verilerini iyi işlemek, sağlam hedefleme taktikleri geliştirmek çok önemlidir. Türkiye'de bu çalışmalar inşaat alanında yapılmış, çok kısa zamanda da çok verimli sonuçlar alınmıştır.

10. Tekrar Hedefleme ve Çevrimiçi Davranış Analizi: Lokasyon, demografik, ses grubu, satın alma davranışları kişinin webde dolaşmasına, sosyal medya ve e mail davranışlarına göre yerleştirilen çerezlerle yönetilebilmektedir.

11. Bulut: Kişiye özel veri, müzik ve dosyaların sonsuz bir dijital platformda saklanması, arşivlenmesi ve istediğiniz zaman kullanımını mümkün kılmaktadır.

12. Bloglar: İngilizce weblog kelimesinin kısa ve yaygınlaşmış adıdır. Kısaca internet günlügü̈/e-günlük olarak ifade edilen, teknik bilgi ve donanım gerektirmeyen, kullanımı ve yönetimi kolay, zengin fonksiyonlu kişisel web alanları olan bloglar, sahiplerini hem yazılı hem de görsel içerik üreten yorumlarıyla internet ortamında tüm dünyaya ulaşabiliyorlar. Yeni medyanın yeni kalemleri oldular. Günümüzde reklam verenlerin halkla ilişkiler çalışmalarının da parçası haline geldiler. Böylelikle en etkin mecra olan ağızdan ağıza halkla ilişkiler yapılabilmektedir.

Müşterilerin kendi aralarındaki konuşmalara reklamlardan daha fazla güvendiğini gören kuruluşlar, sosyal mecrada kendilerine yer açmaya çalıştılar ve internet reklamlarına ağırlık verdiler. Böylece, internetin geleneksel mecralardan aldığı pay da düzenli olarak arttı. IAB Türkiye dijital reklam harcamaları AdEx-2012 Raporu'na göre; dijital reklam yatırımları 2012'de geçen yıla göre \%30 artışla 943 milyon TL oldu. Ancak günümüzde yeni medyadaki birçok farklı disiplin beraber bütünleşik kullanılmaktadır. 


\section{Saadet UĞURLU}

\section{Dijital İletișimde Çoklu Davranıșlar (Multitasking)}

Teknolojinin gelişmesi tüketici alışkanlıklarını değiştiriyor. Artık bir gözümüz televizyonda diğeri mobil cihazlarda. Kullanıcıların davranışları da sahip oldukları cihazlara göre değişiyor. Önceden televizyon izlerken sadece programa odaklanırken artık bir yandan sosyal ağ hesabımıza göz atıyor, maillerimizi kontrol ediyor ve hatta tabletlerimizden aynı anda başka bir programı daha izlemeyi tercih ediyoruz. Mobil cihazlar taşınabilir olduklarından kullanıcıları da çoklu davranışlar göstermeye itiyor.

BI Intelligence'ın 2013 yılı içerisinde yayınladığı global düzeyde yapılan bir araştırmaya göre tablet sahibi olan insanların çok büyük bir çoğunluğu TV izlerken yanlarında tabletlerinin de olduğunu belirttiler.

Üsküdar University Journal of Social Sciences Year:2 Issue:2 Ak1llı telefon kullanıcılarının, televizyon izlerken akıllı telefon kullanma oranlarına bakıldığında \%39'luk bir dilimin her gün televizyon izlerken aynı zamanda akıllı telefonlarını kullandıklarını görüyoruz. 2013 yılı içerisinde hazırlanan, İstanbul'da yaşayan ve 25-54 yaş arası kullanıcıların dâhil edildiği bir araştırmaya göre çoklu davranışlar \%93'lük bir oranla en çok akıllı telefonlar üzerinden gerçekleştiriliyor. Cep telefonu \%84, Tablet \%79, Laptop \%73 Demografik açıdan incelendiği zaman TV karşısında çoklu davranışlar cinsiyete ve yaşa göre değişiklik gösteriyor. ${ }^{18}$ Erkekler kadınlara göre televizyon karşısındayken daha çok tabletleriyle meşgul oluyorlar. 35 yaş ve üstü olanlar ise 25-34 yaşındakilere oranla daha çok izlediklerine odaklanıyor, mobil cihazlarını kullanmayı daha az tercih ediyorlar.

Kullanıcılar farklı cihazlarda farklı çoklu davranış nedenlerine sahipler. Reklam aralarında vakit geçirmek için ikinci ekranı tercih edenler, televizyonda gördüğü herhangi bir şeyin doğruluğunu tespit etmek isteyenler, yarış programlarında oy vermek, programı izleyen diğer arkadaşlarla mesajlaşmayı tercih edenler gibi. Yine çoklu davranış nedenleri

18 "Yeni Teknoloji ve Yeni Tüketici”, Madreport Dergisi, Ocak 2014, s.14-15 


\section{Marka Iletișiminde, Yeni ve Sosyal Medyada İcerik Yönetimi}

de kullanıcıların sahip oldukları cihazlara göre değişiyor. Geliş̧en teknoloji ve beraberinde değişen tüketim alışkanlıklarımızla beraber bazı gerçekler göz önüne seriliyor. Artık çevrimiçi bir hayat yaşıyoruz. Her ne kadar çevrimiçi hayatımıza göre yükselişe geçse de birbirini ikame etmiyorlar ve birbirleri içerisinde entegre ediliyorlar.

Markalar alternatif araçlar kullanarak, etkisini kısa sürede görebilecekleri farklı kampanyaları aynı dilde çoklu kanallara kurgulayarak, başarılı sonuçlar elde edilebilir. Firma ve markalar düzenli olarak çoklu kanal analitik sistemleri entegrasyonuna, içerik yönetimine ve kampanya uygulamalarına yatırım yapmalı, uygulamacılar eğitilmeli ve tüm bunların sürdürebilir olmasına dikkat edilmelidir. Ancak böylelikle hızla değişen hedef kitlenin taleplerine doğru cevabı verebilir ve rekabette varlıklarını sürdürebilirler.

10 Eylül 2013'te İstanbul'da gerçekleşen ADTech ${ }^{19}$ Marketing basın toplantısında grubun Ceo'su Erhard Neuman yaptığı konuşmada Avrupa digital reklam pazarının 2012 'de $\% 11$ büyürken Türkiye pazarının $\% 30$ büyüdüğünü söyleyerek bu büyümenin daha da devam edeceğini belirtti. ${ }^{20}$

Üsküdar

Üniversitesi Sosyal Bilimler Dergisi YIL:2 Sayı:2

Günümüzde içerik ve reklam ayrılamaz hale geldi. Kullanıcıları sayfada tutmak için çaba sarf ediliyor. Kullanıcıların sayfada oyalanması ve meşgul edilmesi için yeni araçlar çıktı. Oyun, video, hepsi bir arada sunuluyor. Tek bir araç değil, tüm elemanlar bir arada bütünleşik kullanılmaya başlandı. iPhone, iPad, tablet, vb. gelecekte daha da önemli olacak. Multi Device World/Çoklu Cihaz Kullanımı, tüm bu teknolojinin ortak programda toplanarak daha etkin kullanılması için ana uygun içerik, görsel oluşumu gereklidir. İlk adım olarak kullanılmak istenen iletişim aracının kullanım amacına bakılmalı ve ona uygun bir içerik olmasına dikkat edilmelidir.

19 1998'de Frankfurt'ta kurulan, Adserver hizmeti veren ADTech, 2007 yılında AOL tarafından satın alındı. Şu anda 39 ülkede ve 680'den fazla müşteriye hizmet veriyor.

20 Erhard Neumann, "Manage the online marketing opportunities and be ready for the changes", Adtech Marketing, İstanbul 2013. 


\section{Saadet UĞURLU}

Üsküdar University Journal of Social Sciences Year:2 Issue:2

Bilginin günden güne daha da değerli hale gelmesi ve $3 G^{\prime}$ nin hizla yayılımı mobil araçların yaşamın her alanına entegre olmasına neden olmuştur. Akıllı cep telefonları, özellikle son zamanlarda ülkemizde de firmaların çalışanları için en çok tercih ettikleri mobil cihazlar haline gelmiştir. Ak1llı telefonlar, kişisel bilgisayarlar ile telefonun ve birçok fonksiyonun birleşmesiyle oluşmuş mobil cihazlardır (Tablet, Set up). Tek bir kimlikle, bir günde telefonda geçirdiğimiz ortalama süre 17 dakika, tablette 30 dakika, masaüstü bilgisayarda 39 dakika iken, TV'de bu süre 43 dakika, karışık (multi) kullanımda ise \%34 kullanıyoruz.

Yeni nesil reklam araçları daha çok görsel içermektedir. Görsel çok önemlidir. Daha az metin, sade, tıklama imkânı, temiz sayfa... Tek bölümde mobil, video, oyun, görsel, eğlence, dikkat çekici tüm unsurlar farklılığı yaşatma hazzı... Zengin medya reklamları (Rich Media Works) öncesinde var olan tek klik ile siteye yönlendirme yerine; zengin, multi interaktif, belirlenen hedef kitlenin hemen dikkatini çeken, ürün seçimi yapılan, kullanımını izah eden video, eğlence unsurları içeren oyunlarla sayfada kalma süresini uzatan, replay imkanı olan, tam ekran olanağ olan, sosyal medya uyarlanmış, online imkanı olan, vb. video kullanımı hem gelişimi hem de etkinliği en yüksek, her formata (TV, Telefon, vb.) uyumlu konsept oluşumlu (Application based formats) yeni teknoloji kullanılmaktadır. Özellikleri; yüksek kullanıcı ve interaktif, yüksek ilgi ve ürün efektlerinin sunumu kolay, müşteriye satış noktası direkt ulaşabilir, daha az çevrimdışı, daha eğlenceli olabilir. Avantajları arasında istenen hedef kitlenin sosyo-ekonomik statü seçimi yapılabilmesi, beğenilerini ya da olumsuz düşüncelerini anında alabilmek imkânını sağlar. Sorun ise genel kullanımda bu teknolojinin daha standart üstü teknoloji gerektirdiğinden kullanım alanları şimdilik sınırlı olabilir. Akı1lı teknolojinin gerekliliğini şöyle sıralayabiliriz:

1. İçerik tüm formatlara uygun oluşturulmalı. Tüm ekranda açılmalı.

2. Etkileşime ve değişime açık modüler yapıda yapılmalı, çeşitli yüklemelere imkân vermelidir. 


\section{Marka Iletișiminde, Yeni ve Sosyal Medyada İcerik Yönetimi}

3. Ölçümleme ve raporlama yapılabilmeli.

4. Uyumlu olmalı.

Teknolojideki gelişmeler ile yayıncıllk ve teknoloji iç içe geçti. Bu durumun sonucu olarak yeni medya düzeninde önceden ayrı ve farklı dünyalar olan yayıncılar, kablo şirketleri, eğlence firmaları, telekom şirketleri, bilgisayar üreticileri ve internet kullanıcıları bir araya geldi. Değişen ve gelişen dünyada; medya içeriğinin tüm kanallara akışını hızlandırmak, medya gelirlerini artırmak, pazarı büyütmek, kullanıcı yorumlarını fazlalaş̧ırmak durumundalar. Bu farklı medya teknolojilerini kullanmayı, akışı tamamı ile kontrol etmeyi, diğer kullanıcılar ile etkileşime girmeyi öğreniyorlar.

Dijital iletişim bugün bağlantıları meydana getiriyor, topluluklar oluşturuyor ve daha önce düşünülemeyen yollardan hareketler organize ediyor. Online iletişim sırasında uzun hikâyeler anlatmak kısa mesajlar ve cümleler kullanmak başlıklara konulara ve alt başlıklara dikkat etmek çok önemlidir. Ayrıca yazı diliniz ve vermek istediğiniz mesajlar basit bir dille anlatılmalıdır.

\section{Sonuç}

Yeni ve sosyal medya, daha geniş hedef kitlelere hızlı ve etkin erişmede, bireyleri birer mecra ve hedef kitleleri artık pasif izleyici haline getirirken iletişim daha etkin ve katılımcı olmaktadır. Yeni tüketici fikirlerini, tepkilerini, ihtiyaçlarını ve isteklerini daha kolay ve cesurca dile getirmektedirler. Dolayısıla kurumların, etkin hedef kitleleriyle başa çıkabilmeleri için geleneksel iletişim dinamiklerini değiş̧irmesi gerekmektedir. Bunun için marka iletişim alanı içinde değişim yönetiminin de ele alınması düşünülmektedir.

İletişimdeki değişim ve dijitalleşmenin sınıları yağmur bulutları gibi belirsizdir. Tüm sektörler gibi, marka iletişimi de bu değişimi yakalamaya 


\section{Saadet UĞURLU}

çaba gösteriyor. Ancak bu arada iletişimin özünden çok cihazlara ve internetin sunduğu teknolojik imkânlara odaklanılıyor. Ancak teknoloji ne kadar gelişirse gelişsin, insanların pek çok temel ihtiyaçları aynı kalıyor. Kuruluşlarında gidecekleri yol "insanı anlamak" tan geçiyor. Onların fiziki ve duygusal ihtiyaçlarını, beklentilerini anlamak gerekiyor. Unilever Türkiye CEO'su İzzet Karaca'nın da belirttiği gibi, değişim büyük oranda insanlardan kaynaklanıyor. Biz de bu nedenle, insanları pazarlama stratejimize dâhil etmek için değişik yollar arıyoruz. Dijital dünya, bize bu firsatı fazlasıyla sunuyor. "Insanların sadece bizim marka öykülerimizi dinlemekle kalmayıp, kendi öykülerini de anlatmalarına yardımcı olmak istiyoruz." ${ }^{21}$

Teknolojik yenilikler insanın ve toplumun yaşamını kolaylaştırmak içindir. Ancak tek başına yeterli olmayacaktır. Bu teknolojik imkânlarla

Üsküdar University Journal of Social Sciences Year:2 Issue:2 kuruluşlardan sağlam değerlere sahip olmaları, toplum, çevre, insanlar ve gelecek dünya için çalışmalarını talep ediyorlar. İçine kapanık, dışarıya bilgi vermeyen hiyerarşik yapılar şeffaflaşmak ve sadeleşmek zorunda kalacaklardır. İnsanların yaşama, eşitlik, güvenlik ihtiyaçlarını karşılamak zorunda olan devlet yönetimleri bundan daha da derin etkilenecektir.

Marka ve kurumlar işe çevrimiçi tüketici algısını yönetme işini çok ciddiye almakla başlamalı. Sonrasında marka ve rakipler hakkında konuşulanları dinlemek, pazarlama iletişim stratejisinde buna göre güncelleme yapmak, ürün ile ilgili zayıf noktalarda kaliteyi arttırırken, tüketici memnuniyetini yükseltip, tüketicilerin bu olumlu deneyimleri paylaşmalarını sağlamak gereklidir. Markalar artık söylediklerine göre değil de yaptıklarına göre yargılanıyorlar. Artık tüketicinin genel görüşleri yerine arkadaş tavsiyesi ya da deneyimleri satın almada daha etkin. Satış ve hizmet ögelerinin yanı sıra modern hayatta, kişilerin hayatlarına verdikleri önem ve kattıkları değer daha önemli olmuştur. Onların davranışlarını, nasıl yaşadıkları bilmemiz, onlara dokunmamız ve empatik iletişim kurmamız gerekmektedir.

21 Fatoş Karahasan, "Dijital Pazarlamanın Kuralları-Taşlar Yerinden Oynarken” Doğan Kitap Yayın, 1. Bask1 Kasım 2012 s.96 


\section{Marka Illetișiminde, Yeni ve Sosyal Medyada İçerik Yönetimi}

Kitleleri yöneten medya yerine kitlenin yönettiği medya, hem kitlesel hem bireysel iletişim imkânı sunuyor. Önerilen son uygulamalar; alternatif araçlar kullanarak, etkisini kısa sürede görebilecekleri kampanyalar ile aynı dilde çoklu ve doğru içerikler üreterek, başarılı sonuçlar elde edilebilir. Firma ve markalar düzenli olarak çoklu kanal analitik sistemleri entegrasyonuna, içerik yönetimine ve kampanya uygulamalarına yatırım yapmalı, uygulamacılar eğitilmeli ve tüm bunların sürdürebilir olmasına dikkat edilmelidir. Firmalar ancak böylelikle hızla değişen hedef kitlenin taleplerine doğru cevabı verebilir ve rekabette varlıkları sürdürebilirler. Marka iletişimi hak ettiği değerini buluyor. İletişim y1llardır neredeyse sadece medya üzerine özel olarak odaklanan bir disiplin halinden; günümüzde yeni teknolojilerle, duygusal bağ kurarak insan odaklı hale getiriliyor.

\section{KAYNAKCุA}

A. Mattelart ve M.Mattelart, Illetişim Kuramları Tarihi, çev. M. Zıllığlu, (İstanbul: İletişim 1998).

David Crowley, Paul Heyer, Illetişim Tarihi, çev. Berkay Ersöz, (Ankara: Siyasal 2011)

Erhard Neumann, "Manage the online marketing opportunities and be ready for the changes", Adtech Marketing, İstanbul 2013.

Fatoş Karahasan, Dijital Pazarlamanın Kuralları - Taşlar Yerinden Oynarken, Doğan Kitap Yayın, 1. Baskı Kasım 2012

Filiz B. Peltekoğlu, Halkla İlişkiler Nedir?, (İstanbul: Beta 2012).

G. Thomson, İnsanın Özü, çev. Celal Üstel, (İstanbul: Payel 1976).

İzzet Bozkurt, Pazarlama İletişiminde Sihirli Dokunuşlar, (İstanbul: Mediacat 2013). 


\section{Saadet UĞURLU}

Levent Yaylagül, Kitle Illetişim Kuramları, (Ankara: Dipnot 2013).

Manuel Castells, ' Information Technology, Globalisation and Social Development", UNRISD Conference On Information Technologies and Social Development, Plais des Nations, Cenova, 22-24 Haziran 1998.

Üsküdar University Journal of Social Sciences Year:2 Issue:2

, The Rise of the Network Society; The Information Age: Economy, Society and Culture, Volume 1. (Oxford: Blackwell 1996). Marshal Mcluhan, The Medium is the Message, (London: Penguin Books 1967).

Marshall Mcluhan ve Bruce R.Povers, Global Köy, çev. Bahar Ö.Düzgören, (İstanbul: Scala Yayın 2001) s.123

Metin İnceoğlu, Tutum Algı İletişim, (Ankara: Siyasal 2011).

"Mobil İnternetin Hızlı Yükselişi, Mobil Uygulama Pazarına da Göz Kirpiyor", IPSOS,

Erişim 29.12.2015, http://www.ipsos.com.tr/node/984

Nick Stevenson, Medya Kültürleri-Sosyal Teori ve Kile İletişimi, çev. Göze Orhon-

Philip Kotler, Hermann Kartaya, Iwan Setiawan, Pazarlama 3.0, çev. Kıvanç Dündar, (İstanbul: Optimist 2010).

Scott David Meerman, Pazarlamanın ve İletişimin Yeni Kuralları, (İstanbul: Mediacat 2010).

“TGI Türkiye 2007-2008-2009 Starcom Media Vest Insighter Vol.3: Türk Tüketicisinin Teknolojiyle Uyumu 2.0”, IAB Türkiye, Güncelleme: 22 Mart 


\section{Marka Illetișiminde, Yeni ve Sosyal Medyada İçerik Yönetimi}

2013 18:01, Erişim 29.12.2015, www.iabturkiye.org

Thomas L. Friedman, Dünya Düzdür, (İstanbul: Boyner, 2006).

Tom T. Stonier, The Communicative Society, çev. Nur Nirven, IPRA-HDD Altın kitap5: İletişim Toplumu, (İstanbul: Rota 1998).

“Türkiye İnternet Kullanıcı Sayısı: 26.6 Milyon”, E Ticaret Mag, 19 Nisan 2013, Erişim 29.12.2015, http://eticaretmag.com/turkiye-internet-kullanicisayisi-26-6-milyon-iab-turkiye-subat-2013/

"Yeni Teknoloji ve Yeni Tüketici” Madreport Dergisi, Ocak 2014

"ZMOT - Ways to Win Shoppers at the Zero Moment of Truth", Google Inc., Haziran 2012, s.7, Erişim 29.12.2015, https://ssl.gstatic.com/think/ docs/2012-zmot-handbook_research-studies.pdf 